\title{
DEVELOPMENTAL VARIATION IN THE EXPRESSIVITY OF GENES CAUSING CHROMOSOME BREAKAGE IN RYE
}

\author{
H. REES \\ Agricultural Botany Department, University College of Woles, Aberystwyth
}

Received 12.i.62

\section{INTRODUCTION}

IN order to understand better how tissues and organs become differentiated during development it is clearly important to investigate in detail the causes of change at cell level, where such differentiation must, ultimately, be initiated. From a cytological standpoint pollen mother cell tissue in anthers is admirably suitable for this purpose. One advantage is that pollen mother cells function, in respect of nuclear division at meiosis, more or less synchronously and thereby provide large populations of developmentally comparable cells for analysis. Such departure from synchrony that exists in their behaviour is measurable and is in itself useful for certain kinds of inquiry. Another advantage of this tissue is that the phenotypic variation which arises in individual cells during their development can easily be assessed cytologically for a considerable number of nuclear characters.

In earlier work on rye (Rees and Naylor, 1960) an investigation was made of variation in the chiasma frequency in pollen mother cells (p.m.c.) within anthers. It was found that one of the factors closely associated with this variation was the timing sequence in which cells entered division. Thus the first cells in an anther to reach metaphase-I had higher chiasma frequencies than those dividing later. On theoretical grounds (see Darlington, 1940) it is probable that the relation between the timing of division and this variation in chromosome behaviour is causal. If this is so it might then be expected that developmental variation in the timing sequence of cells undergoing meiosis might well affect other aspects of chromosome behaviour. To test this an investigation has been made of variation in spontaneous chromosome breakage in p.m.c. to discover what influence, if any, the timing of the divisions has upon its expression.

\section{MATERIAL AND METHOD}

The p.m.c. investigated are from anthers of an inbred line, $P_{I_{3}}$, which is known to exhibit a genotypically controlled chromosome breakage restricted to meiosis. The type of breakage has been described in detail elsewhere (Rees and Thompson, 1956). Briefly, the chromosomes break during early prophase before splitting, producing bridges with acentric fragments at first anaphase or during second division.

Breakage was scored in anthers from plants fixed on the same day. From about two hundred cells in each anther an estimate was made of the proportion of cells which had reached second division of meiosis or later, tetrad, stage. This proportion 
provides a timing index (T.I.) of division for each anther. Low T.I. values represent anthers where only a small proportion, the earlier cells to divide, have reached second division; high T.I. where later cells are included.

Breakage was next assessed as the proportion of these p.m.c. at second division and tetrad stage which contained acentric fragments. The reason for confining the estimate of breakage to second divisions and tetrads and for excluding the first anaphases, when the fragments are first shed, is that some fragments remain attached to centric arms at first anaphase and are consequently difficult or impossible to detect.

With these two kinds of information it is then an easy matter to determine whether breakage is in any way correlated with the sequence of cell division.

\section{TABLE I}

The percentage of pollen mother cells at second division which show chromosome breakage. T.I. values relate to the sequence of cell division (see text)

\begin{tabular}{|c|c|c|c|}
\hline Plant & Anther & $\begin{array}{l}\text { Per cent. p.m.c. } \\
\text { with breakage }\end{array}$ & T.I. \\
\hline I & $\begin{array}{l}1 \\
2 \\
3 \\
4 \\
5 \\
6 \\
7 \\
8 \\
9\end{array}$ & $\begin{array}{l}17 \\
14 \\
13 \\
18 \\
22 \\
14 \\
10 \\
12 \\
14\end{array}$ & $\begin{array}{r}85 \\
75 \\
98 \\
95 \\
45 \\
100 \\
100 \\
100 \\
100\end{array}$ \\
\hline 2 & $\begin{array}{l}\text { I } \\
2 \\
3 \\
4 \\
5\end{array}$ & $\begin{array}{r}28 \\
12 \\
7 \\
17 \\
18\end{array}$ & $\begin{array}{r}18 \\
100 \\
100 \\
42 \\
79\end{array}$ \\
\hline 3 & $\begin{array}{l}1 \\
2 \\
3\end{array}$ & $\begin{array}{r}8 \\
12 \\
14\end{array}$ & $\begin{array}{l}93 \\
46 \\
69\end{array}$ \\
\hline 4 & $\begin{array}{l}1 \\
2\end{array}$ & $\begin{array}{l}21 \\
22\end{array}$ & $\begin{array}{l}60 \\
6_{4}\end{array}$ \\
\hline 5 & I & 28 & 55 \\
\hline
\end{tabular}

\section{RESULTS}

\section{(i) Variation between anthers}

The T.I. values and percentages of p.m.c. with breakage are given for each anther in table I. In fig. I the results, as angular values, are also presented in a graph in which the amount of breakage is plotted against the T.I. values.

From the graph it appears that breakage is strongly correlated with the T.I. It will be seen that breakage is about one and a half times greater in anthers with a T.I. of 20 as compared with those of T.I. go. Since anthers with a T.I. of 90 include breakage in early 
as well as late cells this means that about three times as many of the p.m.c. dividing early contain fragments as compared with p.m.c. dividing later.

The negative correlation is confirmed by statistical analysis. The

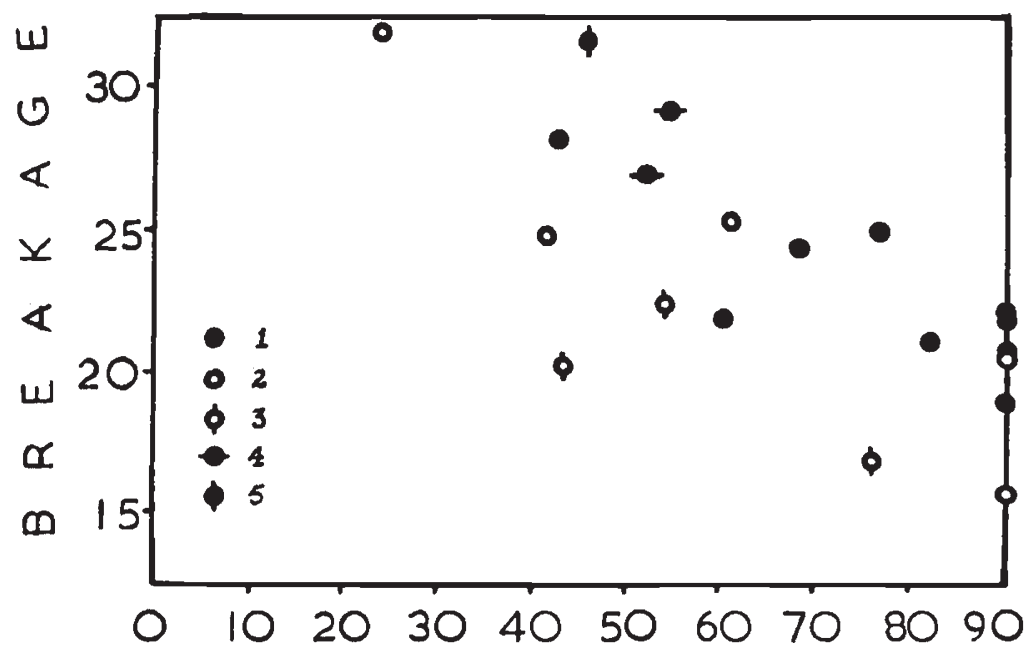

FiG. 1.-The proportions of p.m.c. with chromosome breakage plotted against the timing index $(T . I$.$) . Both values in angles.$

TABLE 2

The analysis of variance of the regression of breakage on T.I.

(after angular transformation)

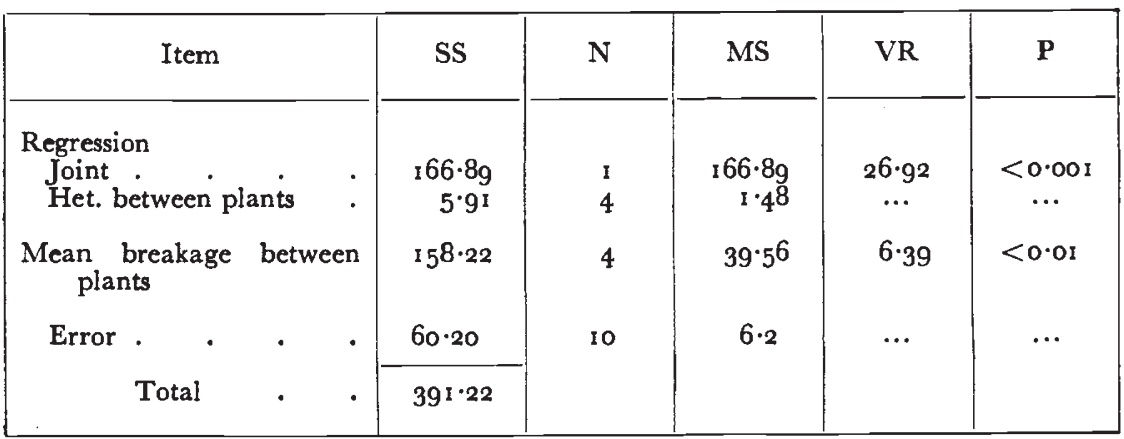

regression analysis of variance given in table 2 shows a significant regression with a negative slope. There is no heterogeneity between plants with respect to this regression although the mean breakage varies significantly between different plants.

\section{(ii) Variation within anthers}

It is known from previous work on rye (Rees and Naylor, 1960) that cells in different regions along the length of an anther are not completely synchronised in their division. Thus, if an anther is divided transversely into four equal sections it is found that the cells 
in the basal sections divide before those in the distal. Other aspects of chromosome behaviour, e.g. chiasma frequency (Rees and Naylor loc. cit.), also vary in relation to the spatial distribution of cell groups. It is therefore worth inquiring whether the correlation established between chromosome breakage and T.I. applies consistently throughout all parts. Also, whether the amount of breakage is variable between the different sections.

The sequence of division. When anthers of $P_{13}$ are cut transversely into four sections the order of division is found to be 2, I and 3, 4, where $I$ and 4 are basal and distal segments respectively. This agrees

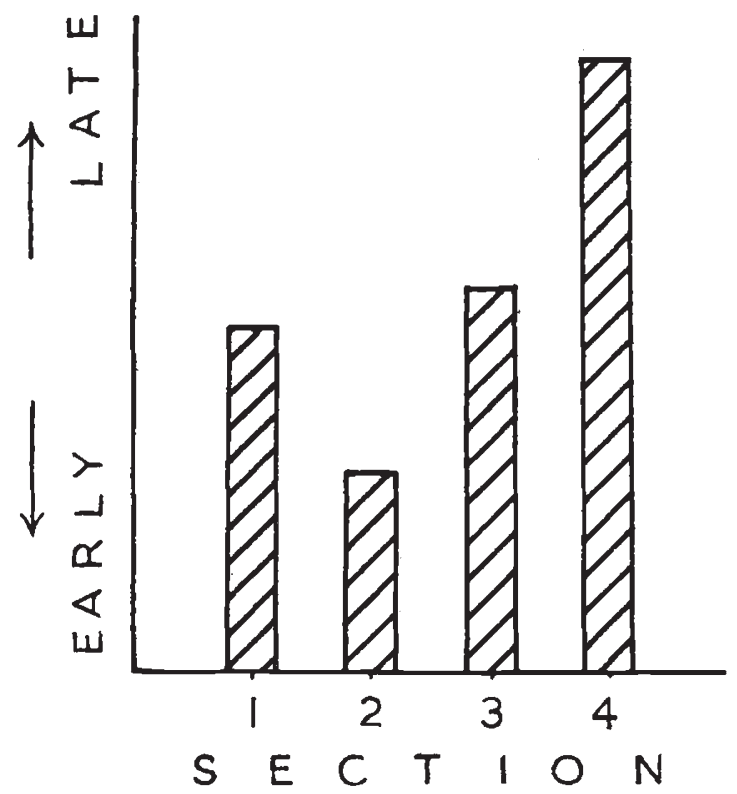

Fig. 2.-The relative sequence of division of the four sections of a rye anther. I is the basal section, 4 the distal. Data from 21 anthers. Sections with the shortest columns in the histogram are the most advanced. See text.

well with the previous work referred to above. Actual data from 21 anthers are represented in fig. 2. In each anther the section most advanced in division was given a score of $\mathrm{I}^{\prime}$, the next in order of division $2^{\prime}$, then $3^{\prime}$ and the least advanced $4^{\prime}$. The relative scores for each section appear in the histogram.

Correlation within sections. Data on T.I. and breakage are available for the separate sections of most of the anthers represented in table $\mathrm{I}$. These values, which were calculated and are expressed in the same way as for whole anthers, are given in table 3 .

A negative correlation is indicated in all four sections: early cells in each display greatest breakage. This is confirmed in the analysis of variance in table 4 where the joint regression is seen to be significant.

The analysis shows no heterogeneity of regression within sections between different plants. On the other hand the mean square for 
TABLE $_{3}$

Per cent. p.m.c. with breakage and T.I. values in each of four sections of $\mathrm{P}_{\mathrm{I} 3}$ anthers

\begin{tabular}{|c|c|c|c|c|c|c|c|c|c|}
\hline \multirow{2}{*}{ Plant } & \multirow{2}{*}{ Anther } & \multicolumn{2}{|c|}{ Section I } & \multicolumn{2}{|c|}{ Section 2} & \multicolumn{2}{|c|}{ Section 3} & \multicolumn{2}{|c|}{ Section 4} \\
\hline & & $\begin{array}{l}\text { Per cent. } \\
\text { breakage }\end{array}$ & T.I. & $\begin{array}{l}\text { Per cent. } \\
\text { breakage }\end{array}$ & T.I. & $\begin{array}{l}\text { Per cent. } \\
\text { breakage }\end{array}$ & T.I. & $\begin{array}{l}\text { Per cent. } \\
\text { breakage }\end{array}$ & T.I. \\
\hline 1 & $\begin{array}{l}1 \\
2 \\
3 \\
4 \\
5 \\
6 \\
7 \\
8 \\
9\end{array}$ & $\begin{array}{r}20 \\
10 \\
12 \\
14 \\
20 \\
14 \\
7 \\
14 \\
10\end{array}$ & $\begin{array}{r}94 \\
100 \\
100 \\
98 \\
20 \\
100 \\
100 \\
100 \\
100\end{array}$ & $\begin{array}{r}12 \\
14 \\
14 \\
6 \\
24 \\
13 \\
13 \\
9 \\
9\end{array}$ & $\begin{array}{r}100 \\
100 \\
100 \\
98 \\
70 \\
100 \\
100 \\
100 \\
100\end{array}$ & $\begin{array}{r}14 \\
18 \\
12 \\
26 \\
\ldots \\
10 \\
8 \\
9 \\
15\end{array}$ & $\begin{array}{l}100 \\
100 \\
100 \\
100 \\
\ldots \\
100 \\
100 \\
100 \\
100\end{array}$ & $\begin{array}{l}22 \\
\ldots \\
17 \\
28 \\
\ldots \\
18 \\
11 \\
17 \\
20\end{array}$ & $\begin{array}{c}46 \\
\ldots \\
92 \\
84 \\
\ldots \\
100 \\
100 \\
100 \\
100\end{array}$ \\
\hline 2 & $\begin{array}{l}1 \\
2 \\
3 \\
4 \\
5\end{array}$ & $\begin{array}{r}\dddot{ } \\
\mathrm{I} 4 \\
4 \\
\cdots \\
\mathrm{I} 8\end{array}$ & $\begin{array}{l}\ldots \\
100 \\
100 \\
\dddot{78} \\
78\end{array}$ & $\begin{array}{r}29 \\
10 \\
8 \\
12 \\
14\end{array}$ & $\begin{array}{r}49 \\
100 \\
100 \\
84 \\
100\end{array}$ & $\begin{array}{r}\ldots \\
10 \\
6 \\
21 \\
20\end{array}$ & $\begin{array}{l}\ldots \\
100 \\
100 \\
76 \\
9^{2}\end{array}$ & $\begin{array}{c}\ldots \\
14 \\
8 \\
\ldots \\
19\end{array}$ & $\begin{array}{c}\ldots \\
100 \\
100 \\
\ldots \\
46\end{array}$ \\
\hline 3 & $\begin{array}{l}1 \\
2 \\
3\end{array}$ & $\begin{array}{r}8 \\
18 \\
14\end{array}$ & $\begin{array}{r}100 \\
78 \\
56\end{array}$ & $\begin{array}{r}2 \\
8 \\
20\end{array}$ & $\begin{array}{r}100 \\
96 \\
100\end{array}$ & $\begin{array}{l}10 \\
\cdots \\
6\end{array}$ & $\begin{array}{c}100 \\
\ldots \\
100\end{array}$ & $\begin{array}{l}\mathrm{I} 4 \\
\cdots \\
\cdots\end{array}$ & $\begin{array}{l}72 \\
\cdots \\
\cdots\end{array}$ \\
\hline 4 & $\begin{array}{l}1 \\
2\end{array}$ & $\begin{array}{l}24 \\
20\end{array}$ & $\begin{array}{r}92 \\
100\end{array}$ & $\begin{array}{l}16 \\
20\end{array}$ & $\begin{array}{r}98 \\
100\end{array}$ & $\begin{array}{l}24 \\
26\end{array}$ & $\begin{array}{l}4^{8} \\
5^{6}\end{array}$ & $\begin{array}{l}\cdots \\
\cdots\end{array}$ & $\begin{array}{l}\ldots \\
\cdots\end{array}$ \\
\hline 5 & I & 26 & 62 & 8 & 100 & 29 & $5^{6}$ & $\cdots$ & $\cdots$ \\
\hline
\end{tabular}

TABLE 4

The analysis of variance of the regression of breakage on T.I. within anther sections (after angular transformation)

\begin{tabular}{|c|c|c|c|c|c|}
\hline İtem & SS & $\mathrm{N}$ & MS & VR & $\mathrm{P}$ \\
\hline Regression & & & & & \\
\hline & $\begin{array}{c}370 \cdot 00 \\
53 \cdot 28\end{array}$ & I & $\begin{array}{l}370 \cdot 00 \\
17 \cdot 76\end{array}$ & $16 \cdot 70$ & $<0.001$ \\
\hline $\begin{array}{l}\text { Het. between sections } \\
\text { Het. between plants "within } \\
\text { sections" }\end{array}$ & $37 \cdot 72$ & $\begin{array}{r}3 \\
14\end{array}$ & $2 \cdot 77$ & $\cdots$ & $\cdots$ \\
\hline \multicolumn{6}{|l|}{ Mean breakage } \\
\hline Between sections & $96 \cdot 43$ & 3 & $32 \cdot 14$ & $\ldots$ & $\ldots$ \\
\hline $\begin{array}{l}\text { Between plants } \\
\text { sections " }\end{array}$ & $619 \cdot 34$ & 14 & $44^{\cdot 24}$ & $\cdots$ & $\cdots$ \\
\hline Error & $687 \cdot 15$ & $3^{I}$ & $22 \cdot 16$ & $\cdots$ & $\cdots$ \\
\hline Total & $1864 \cdot 92$ & 65 & & & \\
\hline
\end{tabular}


heterogeneity of regression between sections is significantly greater than that between plants. There is some indication therefore that the slopes vary between sections. The $b$ values are $-0.15,-0.24$, -0.40 and -0.13 for sections $I, 2,3$ and 4 respectively. In section 3 , it appears, the rate of change of breakage on T.I. is greatest. In all sections, however, there is a consistently negative correlation between the breakage and T.I.

The amount of breakage in sections. From the analysis of variance in Table 4 it will be seen that the variation in mean breakage between different sections is not significant. This result in itself, however, is not conclusive and may be misleading because breakage varies with T.I. It follows therefore that comparisons of mean breakage in different sections are meaningful only if the section T.I.'s are similar. Thus, when we consider the mean breakage at the same T.I., 90, for each section (fig. 3) we see a considerable increase in mean

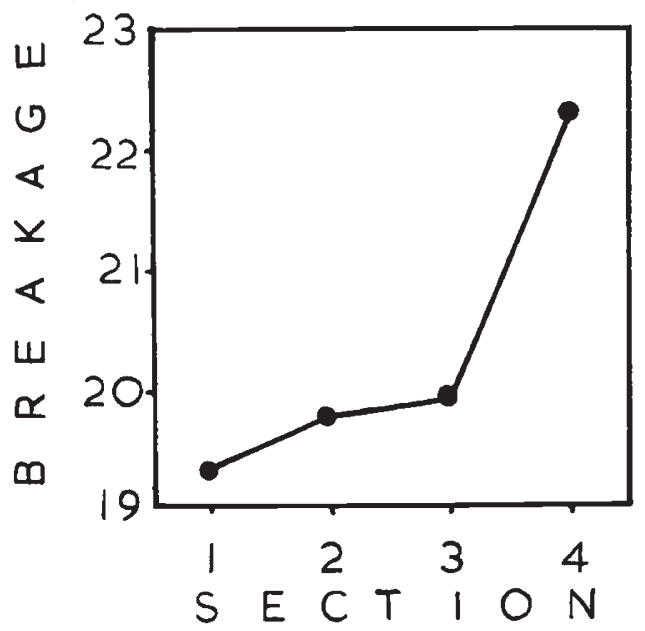

Fic. 3.-The proportions of p.m.c. with chromosome breakage in anther sections of T.I. go. Angular values.

breakage per section as we proceed from base to tip. While the linear regression is not significant $(\mathbf{P}=0 \cdot 10-0 \cdot 20)$ there is some indication here that p.m.c. in sections of the anther dividing later display more breakage than those dividing earlier. This would mean that the correlation between timing and breakage between sections is the reverse of that within them, positive and negative respectively. A more detailed investigation, however, was desirable to test this assumption and this is dealt with in the next section.

Fragments in pollen grains. A most convenient way of comparing the amount of breakage in the four sections is to estimate the number of fragments in a sample of pollen grains in each. This procedure eliminates all the variation in breakage estimates within sections that is dependent on the timing sequences of their component p.m.c. The results of scoring 200 pollen grains in each section of $2 \mathrm{I}$ anthers are 
given in table 5 and in fig. 4, where the number of fragments per Ioo pollen grains is plotted against sections.*

The breakage frequencies were transformed to angles and in table 6 is the analysis of variance of the regression of breakage on sections in linear order from base to tip. The joint regression is highly significant and it is clear that the assumption of higher breakage in the distal segments is confirmed.

TABLE 5

The distribution of acentric fragments in pollen grains. The number of fragments per roo pollen grains is given for each anther section

\begin{tabular}{|c|c|c|c|c|c|}
\hline \multirow{2}{*}{ Plant } & \multirow{2}{*}{ Anther } & \multicolumn{4}{|c|}{ Section } \\
\hline & & I & 2 & 3 & 4 \\
\hline 1 & $\begin{array}{l}1 \\
2 \\
3 \\
4 \\
5 \\
6\end{array}$ & $\begin{array}{l}7 \\
2 \\
5 \\
5 \\
6 \\
4\end{array}$ & $\begin{array}{l}5 \\
8 \\
4 \\
6 \\
7 \\
4\end{array}$ & $\begin{array}{l}9 \\
5 \\
6 \\
6 \\
8 \\
5\end{array}$ & $\begin{array}{r}9 \\
10 \\
9 \\
9 \\
10 \\
4\end{array}$ \\
\hline 2 & $\begin{array}{l}1 \\
2 \\
3 \\
4 \\
5 \\
6\end{array}$ & $\begin{array}{l}6 \\
6 \\
3 \\
6 \\
5 \\
7\end{array}$ & $\begin{array}{l}5 \\
7 \\
5 \\
8 \\
7 \\
8\end{array}$ & $\begin{array}{r}5 \\
7 \\
4 \\
11 \\
8 \\
11\end{array}$ & $\begin{array}{r}10 \\
7 \\
10 \\
9 \\
6 \\
10\end{array}$ \\
\hline 3 & $\begin{array}{l}1 \\
2 \\
3 \\
4 \\
5 \\
6\end{array}$ & $\begin{array}{r}4 \\
5 \\
7 \\
7 \\
7 \\
12\end{array}$ & $\begin{array}{r}4 \\
9 \\
7 \\
10 \\
7 \\
4\end{array}$ & $\begin{array}{l}7 \\
8 \\
8 \\
5 \\
7 \\
4\end{array}$ & $\begin{array}{r}7 \\
8 \\
8 \\
13 \\
11 \\
11\end{array}$ \\
\hline 4 & $\begin{array}{l}1 \\
2 \\
3\end{array}$ & $\begin{array}{r}16 \\
3 \\
3\end{array}$ & $\begin{array}{l}6 \\
3 \\
7\end{array}$ & $\begin{array}{r}10 \\
6 \\
6\end{array}$ & $\begin{array}{r}12 \\
7 \\
8\end{array}$ \\
\hline Mean & & $6 \cdot 0$ & $6 \cdot 3$ & $7 \cdot 0$ & $9^{\cdot 0}$ \\
\hline
\end{tabular}

From the graph in fig. 4 it will also be observed that the breakage in the later dividing sections is less than twice that in the earlier. This compares with a fourfold decrease between early and late cells within sections. The latter gradient is the more severe, as indeed is to be expected from the results of analysing whole anthers where, it will be recalled, earlier dividing cells showed greatest overall breakage.

* If each p.m.c. contained not more than one fragment at meiosis the number of fragments in 100 pollen grains produced should be one-fourth of the percentage p.m.c. with breakage, viz. $5 \cdot 1$. In fact an average of 6.5 fragments are found in each 100 pollen grains. The excess, in part at least, is explained by multiple breaks in some p.m.c. 100 p.m.c. on average contain about 130 fragments. 


\section{DISCUSSION}

The chromosome breakage in $P_{I 3}$ is genotypically controlled. As we have seen the expression of the genes which control this breakage conforms to a well defined pattern, one which is closely associated with and, one must suppose, dependent upon the changing cell environment during growth and development. In the first place the threshold for expression of these genes is restricted to the first prophase of meiosis. In the second place the breakage in p.m.c. varies in accordance with two well-defined gradients within the anthers. There is an increasing breakage from the basal, earlier dividing, sections of the anther to the distal, later dividing sections. And within these

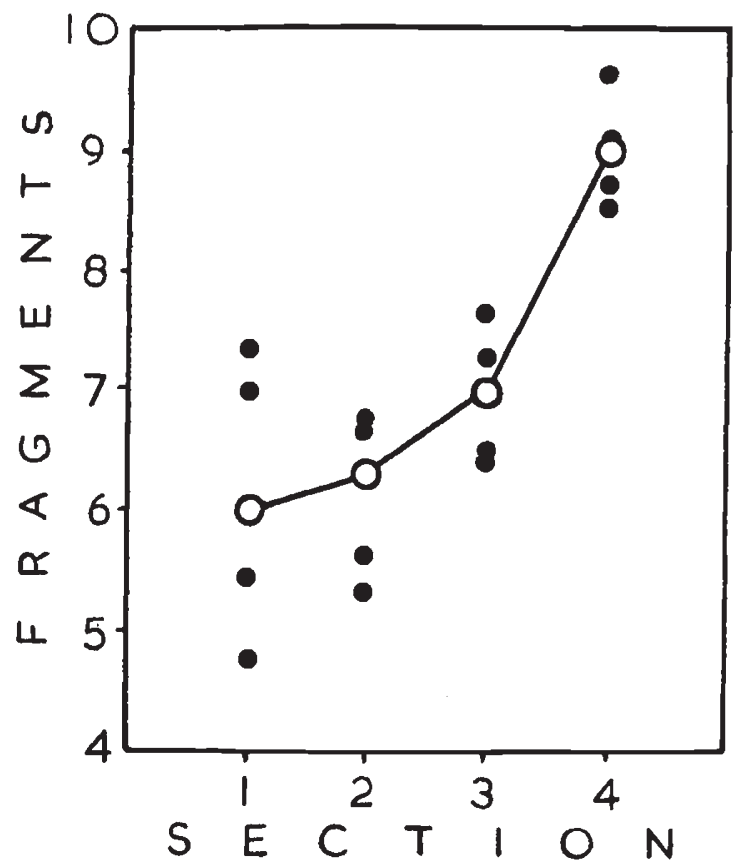

Fig. 4. -The number of fragments per roo pollen grains in sections of rye anthers. Data from 21 anthers in four plants. Open circles give mean values.

sections earlier dividing p.m.c. show greater breakage than those dividing later. The general pattern is summarised in fig. 5 .

These are of course two ways in which the relation between breakage and the timing sequences could be interpreted, namely that the division sequence of p.m.c. is determined by their chromosome breakage or that the breakage is determined by the division sequence. The former, however, can be dismissed because the division sequence of sections of rye anthers is identical in lines with and without chromosome breakage ( $f f$. Rees and Naylor loc. cit.). There is every reason therefore to suppose that the timing sequence is a causal factor in determining the expressivity of these genes causing breakage. 
A further aspect of the variation in the timing of division of p.m.c. needs to be considered, namely its origin. When p.m.c. reach second metaphase at different times they may do so for one of

TABLE 6

The analysis of variance of the regression of fragment frequency (in angles) on section order

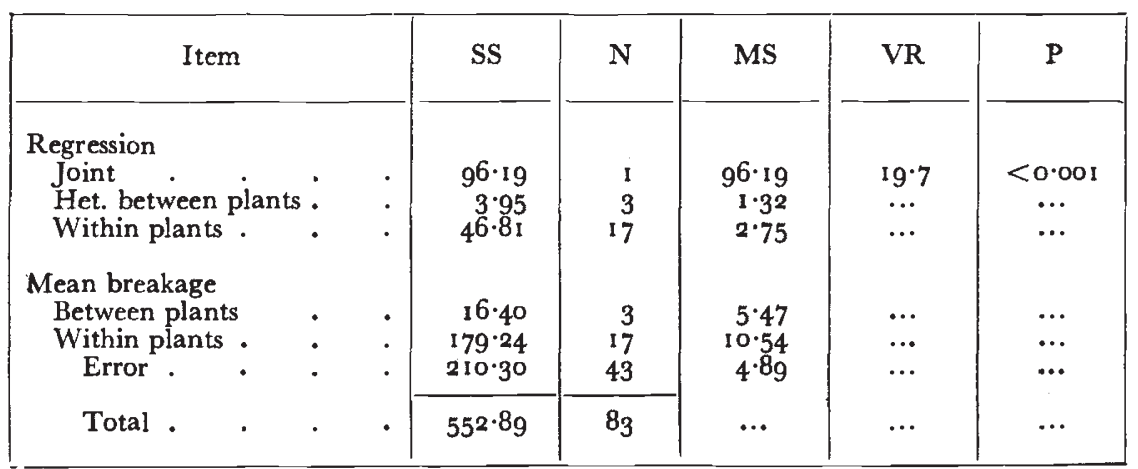

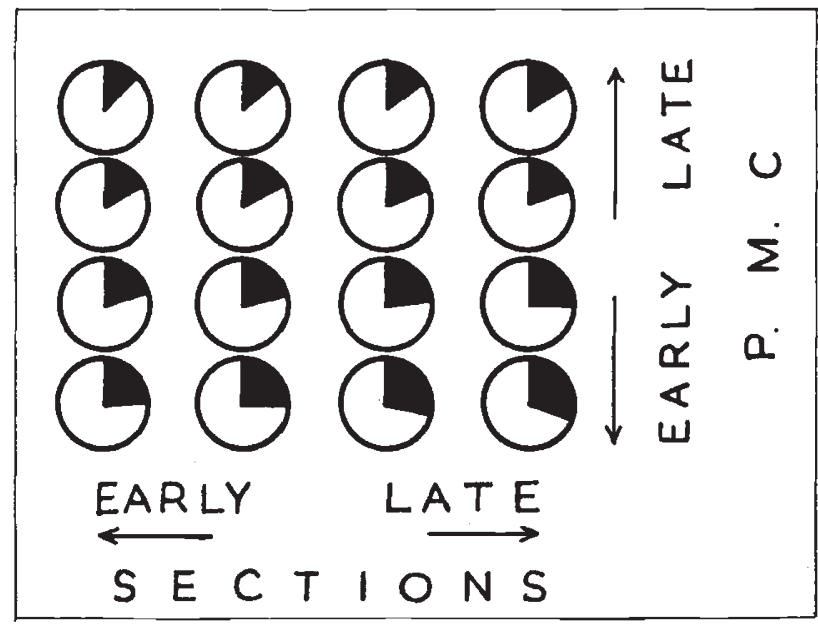

FIG. 5.-Breakage gradients within $P_{13}$ anthers. Breakage (indicated by shading) increases in sections from base to tip, corresponding approximately to the order in which they undergo meiosis. Within sections early dividing p.m.c. show greater breakage than the later dividing cells.

two reasons. They either proceed through meiosis at different rates or begin at different times. In the latter case the p.m.c. would be out of step with one another at the outset of meiosis and the initial causes of timing variation in p.m.c. division, and their consequences, could therefore derive partly from earlier differences-in the mitotic 
rates of the cells from which the p.m.c. are immediately descended. The pre-meiotic mitoses are in fact found to be normally not completely synchronised within rye anthers. It follows that the developmental variation revealed by the chromosome breakage may to some degree be accumulative over a number of cell generations-as indeed was established in a comparable case in Allium by Darlington and Haque (1955). How in physiological terms such variation in division originated is difficult to establish. No doubt it is influenced by the morphology and vascular anatomy of the anther in relation to nutrient supply (see Rees and Naylor) and, in particular, to the diffusion of such material between cells during growth (see Darlington and Haque).

The kind of relation described here between cell phenotype and the timing of cell division is certainly not uncommon. It has been established or inferred in a number of other species. P.m.c. delayed at meiosis in Allium (Darlington and Haque, 1955), Scilla (Rees, 1952), Chrysanthemum (Dowrick, 1953) are cytologically abnormal, with asynapsis or chromosome breakage. In Uvularia an induced postponement of pollen grain mitosis causes abnormal cell wall formation (Barber, 194I). Even the slight asynchrony of meiosis in p.m.c. of normal rye anthers is associated with variation in chiasma frequency (Rees and Naylor, 1960). In wheat hybrids (Wagenaar, 196r) and Bromus hybrids (Walters, 1960) abnormality is also related to cell timing. Variation in recombination with ageing in female mice can be interpreted on the same basis (see Bodmer, $196 \mathrm{r}$, who gives other pertinent examples). And whereas most of this evidence relates to cytological variation in development there is of course no reason to suppose that the relation between the timing of cell division and gene expression is confined to chromosome characters. Rather it indicates that cytological analysis can be a most useful means of recognising and describing these developmental patterns and give, as well, some indication of their causes.

\section{SUMMARY}

I. Patterns of developmental variation are described for a genotypically controlled chromosome breakage in p.m.c. within anthers of an inbred line in rye.

2. The variation in breakage between p.m.c. is closely related to the division sequence of the cells.

(i) The earlier dividing, basal, regions of the anthers show less breakage than the later dividing, distal, regions.

(ii) Within all regions of an anther the earlier dividing cells show more, about three times greater, breakage than the cells dividing later.

3. The relation between the division sequence of the cells and the expressivity of genes causing the breakage is inferred to be causal. 


\section{REFERENCES}

BARBER, H. B. I94I. Chromosome behaviour in Uvularia. F. Genet., 42, 223-257. BODMER, W. F. I $96 \mathbf{I}$. Viability effects and recombination differences in a linkage test with pallid and fidget in the house mouse. Heredity, $16,485-495$.

Darlington, C. D. 1940. The prime variables of meiosis. Biol. Rev., 15, 307-322. DARLINGTON, C. D., AND HAQUE, A. 1955. The timing of mitosis and meiosis in Allium ascalonicium: a problem of differentiation. Heredity, 9, I $17-127$.

DOWRICK, C. J. 1953. The chromosomes of Chrysanthemum. III. Meiosis in C. atratum. Heredity, 7, 2 19-226.

REES, H. 1952. Asynapsis and spontaneous chromosome breakage in Scilla. Heredity, 6, 89-97.

REES, H., AND NAYLOR, B. 196o. Developmental variation in chromosome behaviour. Heredity, 15, 17-27.

REES, H., AND THOMPSON, J. B. 1956. Localisation of chromosome breakage at meiosis. Heredity, 9, 399-407.

WAGRNAAR, E. B. I961. Cytological studies of the development of metaphase I in hybrids between Triticum timopheevi Zhuk. and T. durum Desf. Can. Fourn. Bot., 39, 81 - Io9.

WALTERS, M. S. 1960. Rates of meiosis, spindle irregularities and microsporocyte division in Bromus trinii $\times B$. carinatus. Chromosoma, $I I, 167-204$. 